\title{
STUDENT CHOICE PROCESS OF HIGHER EDUCATION INSTITUTIONS (HEIs) THROUGH UNIVERSITY DIGITAL MARKETING SOURCES
}

\author{
Andriani Kusumawati \\ Division of University Reputation, Ranking Centre, Department of Business \\ Administration, Faculty of Administrative Science, Brawijaya University, Malang, \\ Indonesia
}

\begin{abstract}
New challenges and opportunities faced by HEIs marketers in this digital age. Digital marketing used by university is the utilization of electronic media to promote their institution to the target market. University digital marketing purpose is attracting students and other stakeholders as well as allowing them to interact with the institution through digital media. Yet little research has examined the potential of digital marketing for higher education institution. This study investigates the importance of digital marketing for both university marketers and students. Using qualitative research techniques, the researcher interviewed university recruitment managers, prospective students, current students which have been purposely selected, and thoroughly used secondary data to confirm the effectiveness of university digital marketing in five Indonesian public universities. The potential impact of digital marketing on the university recruitment management were examined along with the differences between traditional marketing and digital marketing. This study has explained various methods of university digital marketing, effectiveness of it and the impact it has on student decision making process in selecting a university. This study has contributed to the similar higher education institutions, university marketers and future researchers by providing a background of making a potential use through university digital marketing strategies.
\end{abstract}

Keywords: digital marketing, university, student, decision making, Indonesia

JEL Classification: M31

\section{Introduction}

Digital Marketing has expanded the boundaries of education. In this era, educational institutions from all over the world are no longer finding it difficult to market themselves to their audience or suffer from a lack of brand awareness. Due to the big spread of information, educational institutions have the chance to show the opportunities that students could get from the service they provide, not only in the country but in a worldwide market (Patrutiu Baltes, 2015).

University involves digital marketing in the current disruptive technology era as an institutional promotion tool. Combination of digital marketing and traditional marketing into whole university marketing strategy is no longer an option, it is vital particularly for students' recruitment success. The growth of digital marketing has changed the approach higher education use technology because universities are aware of the technological habits of the millennia as their potential target market. Digital marketing has assumed a wide spread application across sectors, however in the current context with proliferation digital and social media have gained enormous popularity and are integral parts of the decision making of young students seeking higher education. Marketing in higher 
education sector depend on the improvement and management of connections with current and prospective students as well as alumni (Constaninides and Zinck Stagno, 2011) and social media has become an important medium to assist universities in managing these relationships (Mattson and Barnes, 2009). However, Ernst and Young (2012) predict that although the digital revolution will not eradicate campus-based universities, it will transform how education is delivered and supported, and the way higher education institutions create value. Therefore, the paper aim to explore how the digital revolution has impacted one of the businesses namely higher education institution with wider scope with the implementation of Digital Marketing. Since student are millennial generation in this technology-based era, the greatest influence they have in education is quite interesting to be further examined especially their social media habit for selecting a higher education institution to attend.

Currently, the growth of digital marketing in Indonesia continues to increase quite promising from time to time. Indonesia's digital landscape is rapidly growing with country's over 260 million populations along with rapidly rising number of internet users, striking $40 \%$ of social media penetration rate, and developing infrastructure. Indonesia has a potential to become a focus of digital creativity supported with growing economy, digital literacy, and rising urban population, (GetCRAFT, 2017). Based on Indonesia's Digital and Landscape Marketing Reports conducted by GetCRAFT (2017) describes that the explosion of digital platforms and increased technology savvies are making consumers more discerning about how they spend their time online. Another survey results in 2017 by APJII showed that 143.26 million people or $54.68 \%$ of the total population of Indonesia used the internet. While the composition of internet users is dominated by the age range of 18-34 years which is equal to $49.52 \%$. This situation offers university marketers to think as a business to attract prospects or students to their own channels with persuasive contents, along with other strategies. Digital offers a bright future for marketers since technology improves, there will be more innovative, effective, and greater ways to serve the customers' needs.

On the other hand, since 2015, several of Higher Education institutions in Indonesia have been encouraging to be an autonomous university in terms of management system. Currently, one of emerging agendas that coincides with the rise of Higher Education Long Term Strategy (HELTS) is the need to become a World Class University (WCU) for Indonesian universities (Syahid and Tulung, 2016). Along with this agenda, the Strategic Plan of the Directorate of Higher Education in 2025 HELTS reveals that Indonesia will regard itself as - Smart and Competitive Indonesia in 2025 (Anonim, 2002). This program requires Indonesian Higher Education Institutions (HEIs) to compete with other universities internationally in order to turn into the best. It is also commensurate with the Ministry of Research, Technology and Higher Education which is always reminiscent of all Higher Education in Indonesia, both private and public continue to innovate and Higher Education in Indonesia can no longer only compete with fellow universities in the country, but also prepare to compete with foreign universities (kelembagaan.ristekdikti.go.id, 2018). This strategy is also in accordance with Law of The Republic of Indonesia Number 12 in 2012 on Higher Education which stated that: In order to increase the national competitiveness to face globalization in all sectors, higher education is required to develop science and technology as well as produce intellectuals, scientists and/or professionals who are cultured and creative, tolerant, democratic, strong character, and brave to defend the truth of the nation interest". In this situation, the term 'technology' becomes key considerations that imply the role of digital marketing is prominent. Hence, the issues of digital marketing are crucial in Indonesian Higher Education Institutions to engage with the internalization agenda of HELTS. Consequently, many university marketing professionals has realised the 
importance of implementing social media as a marketing tool for promotional purposes. This paper focuses on the importance of digital marketing for both marketers and students, as well as examines the influence of university digital marketing on the students' choice of higher education institution. Since this study focuses on a public university, it is hope that the results of this study will be applicable to higher education institutions involved in this intensely competitive market.

\section{Digital Marketing and Higher Education Institution}

Sherman (2014) in Best Practices Guide "Proving the Value of Digital Marketing in Higher Education", affirms that higher education has been undergoing a transition for many years. Students become more selective in their school selection due to intensifying competition and rising fees of higher education. In this circumstance, alternate methods of learning are having an impact on the pool of prospective students. As a result, higher education marketing has shifted from glossy brochures to social media and the web to acquire prospective students' attention. Martin (2015) claims that digital marketing has brought the world changes and higher education sector is no exception. Without enrolment growth, colleges and universities will not sustain. College and universities have the challenge of maintaining relevance among students who are increasingly more reliant on technology as a communication source.

In their study, Hayes, Rushman and Walker (2009, cited in Miller, Wardrope and Bridges, 2011) found that 72 percent of students USA said that they preferred interacting with admission staff online rather than meet them face to face. Miller, Wardrope and Bridges (2011) also found that students now prefer instant messaging compared to e-mails. Although, Barnes and Mattson (2008) discovered that college blogs are a very effective way of being in touch with students in USA and around $41 \%$ of universities from the United States of America have a blog of their own, they found that online behaviour can and will influence the decision of students as $89 \%$ of admissions departments felt that social media was "somewhat important" for getting more students. Their study also concluded that most colleges currently are using social media to attract students, but virtual interaction are not replaced face to face communication entirely. This face to face interaction still needed by students when they want to discuss with a professor and an advisor.

Social Media is a very interactive dynamic medium that provides with a lot of opportunities. At the same time it creates challenges for the marketers to develop conforming marketing strategies. Previous researchers have certainly supported this claim that this conformation needs to be carried out in order to stay competitive in the market (Kreutzer and Hinz, 2010; Mangold and Faulds, 2009). Affectivity of traditional media and current marketing strategies using unidirectional communications and mass marketing efforts have been questioned as the target audience seem to have lost trust on this medium (Constantinidines and Fountain, 2008). Customers seem to value this new media more through direct involvement and looks at this from a sense of ownership as they also generate the contents within them (Mangold and Faulds, 2009).

In another research, Barnes and Mattson (2009) revealed that more and more universities are using internet and social media to attract students and online behaviour and social networking has a far reaching effect on the decisions taken by young people. In order to engage the prospective students, universities must utilise cognitive, emotional and behavioural dimensions (Raman and Pramod, 2014). Among these three dimensions, the emotional dimension could easily be approached via social media. Using a regression model to prove that blogs and discussion forums have the maximum effect on 
admissions, the research found that 61 per cent universities included in their research utilised social media for admissions. This study also emphasises. The researchers also claimed that universities require to have a vibrant and informative blog to connect with their stakeholders. However, the a combination of both traditional and new media still needed. In urban areas, another study by Ashok, Apoorva and Suganthi (2015) found that television, social media and websites have the largest effect, text messaging has temporary effect and pamphlets have no effect. This study confirms that yet tertiary institutions continue to use all media for reaching out to students, the level of effectiveness and the return on investment in terms of attracting a numerous students differs from media to media. Whereas all previous research have attempted to investigate the effectiveness of advertisement in influencing students, there is a gap in knowledge of how digital media influence the millenial decision of choosing or not choosing a university.

\section{Research Methodology}

This research is an exploratory research with qualitative approach. The qualitative approach was selected based on the ease to explore, analyse, identify, and understand the phenomenon to get a deeper meaning. This research aims to explore, identify, and understand phenomenon based on several theories related to digital marketing and student decision making process in Higher Education Institutions (HEIs) at a large public university in Indonesia. Data collected by interviewing participants or interviewees regarding phenomena of this research regarding digital marketing on student decision making process - through their way of thinking, personal feelings, opinions and actions. The results of data were analysed by researcher inductively without any interventions or changes. Data interpretation is presented as is and in logical sentences and can be easily to understand. The writing of the research final result is conducted in flexible structure. Two university recruitment managers, two prospective students and current students respectively which have been purposely selected, and thoroughly used secondary data to confirm the effectiveness of university digital marketing in five Indonesian public universities. Thematic analysis (Braun and Clarke, 2006) was employed in this research to identify, analyse, interpret and report on themes located in the qualitative data sets. Thematic analysis aims to expose meaning in the data by ascertaining and evaluating themes (Buetow, 2010) found in qualitative methodology, such as discussions in interviews and focus groups about experiences pertaining to the research question. Patterns of participation were grouped and correlated to the contexts of interactions. Style, register, and "voice" or tone analysis were also used on the data sets to try to discover the dynamics among the participants.

\section{Findings}

Brawijaya University was first established into a state university on January 5, 1963, following a Presidential Decree issued earlier in the same year. This date was later promulgated as UB's anniversary (specifically called Dies Natalies among Indonesian academic society members) with acronym of UNBRA and then UNIBRAW, before UB being inaugurated as the official acronym of Universitas Brawijaya in 2008. With approximately 60,000 students in various degrees ranging from the Diploma Program, Bachelor's Degree Program, Master's Degree Program, Doctoral Degree Program, and Medical Specialist Program, in 16 Faculties, UB is the $5^{\text {th }}$ largest university in Indonesia according to Webometrics World University ranking on 2017. Based on 4ICU World University ranking, UB's position on 2018 is on 4th rank in Indonesia, going upward from the previous year's rank of $6^{\text {th }}$. On Southeast Asia level, UB is on $17^{\text {th. }}$ 
At present, UB's website has a comprehensive and professional design look. Information such as student's admission, selection of degree programs, faculty-related links, and student services are available. However, the website only provides basic information (typically in a roundabout manner) and lacks depth in the info it could provide for potential students. A comment left behind by some of the students particularly mentioned that, "The website is not quite informative" and that information "did not give me confidence applying to UB". There is no complete information of the necessary courses for each degree, or detail on what these courses require. Other information that might be considered important for prospective students such as housing accommodation and location assistance (maps) were not provided and difficult to found. In terms of social media, UB has done well for itself with Facebook with, as of this writing, 34,864 followers, Twitter with 159,000 followers, and Instagram with more than 40,000 followers. Beside these three social media, YouTube, Flickr, and RSS were also utilised by UB. Furthermore, on these social media pages there does not show to much activity from students; most activities are from the university itself with slight to no reposts or comments by the followers.

Finding of this research reported the socio-demographic profile of the sixth participants involving in this study. Out of six participants, two participants were university marketing and public relation administrator followed by two students' currenly enrrolled, and two others were prospective students which associated with a characteristic population of higher school leavers. In terms of digital media, students' awareness is very high, at least in the age group of 18-19 which was the target population for this research, majority of the participants use digital media for getting some or other kind of information out of reference group influence emerged as the driving factor of the digital media usage. Before deciding on the decision-making of the respondents referred to Internet, went to search engines and browsed on university social media, also checked university websites. As per the analysis most of respondents referred to social media before taking decision to select particular university. Facebook was the most referred medium of university official social media platform. For gathering information related to course offered and admission, the official websites of university was the most preferred medium. However, to gather the life sense regarding the university atmospher, social media such as Facebook, Twitter, Intagram, YouTube and RSS appeared to be the most preferred channel.

The research results describe the ways in which the students learn about university and related information through online media. Based on this study, daily student internet usage was beyond expected. Almost $90 \%$ of the respondents use the internet multiple times a day, slightly less than $6 \%$ use the internet once a day and the rest use it less regularly. Based on the collected data, there is a large difference among the devices used to access the internet. Respondents primarily use their mobile phones and laptops to access the internet while other devices and other public computers are not used to a greater extent. It should be pointed out that the respondents were asked two questions about using different communication channels for information access. Respondents rely the most on the social media Facebook when it comes to general university information and students live information at the university, and then on university website when it comes to specific university information such as course offered, admission, student achievement, and academic reputation. For admission related decisions' University website is preferred compare to all other mediums closely followed by search engines. The study also confirmed that very few students are informed through offline media such as university brochures, newspapers, radio or television or directly through campus visit. Gathering information about student helps Higher Education Institutions to clearly identify their target market and to assess any possible threats and potential opportunities for their product or service. 
Table 1. Summary of the Research Findings regarding digital media influence on students' decision-making process of university

\begin{tabular}{|c|c|c|}
\hline \multirow[t]{2}{*}{ Finding } & \multicolumn{2}{|l|}{ Description } \\
\hline & Students & University Marketing Division \\
\hline Learn about university & Online and offline media (mostly online) & $\begin{array}{l}\text { Online and offline media (mostly } \\
\text { online) }\end{array}$ \\
\hline $\begin{array}{l}\text { Frequently medium for } \\
\text { searching }\end{array}$ & Internet & Internet \\
\hline Frequently usage & Multiple time a day & Multiple time a day \\
\hline Length of usage per day & 1-2 hours a day & at least 1 hour a day \\
\hline Devices used to access & Mobile phone & Mobile phone \\
\hline $\begin{array}{l}\text { Communication channel for } \\
\text { information access about } \\
\text { university }\end{array}$ & Social media & Social media \\
\hline $\begin{array}{l}\text { Preferred digital media used } \\
\text { for searching and selecting } \\
\text { university }\end{array}$ & $\begin{array}{l}\text { They utilized social media and } \\
\text { university website to explore } \\
\text { universities that they considered } \\
\text { attending. }\end{array}$ & $\begin{array}{l}\text { They utilized social media and } \\
\text { university website to explore } \\
\text { universities that they considered joining. }\end{array}$ \\
\hline Most digital marketing used & Social media & Social media \\
\hline $\begin{array}{l}\text { Preferred sites of digital or } \\
\text { social media }\end{array}$ & Facebook and Twitter & $\begin{array}{l}\text { University website, Facebook and } \\
\text { Twitter }\end{array}$ \\
\hline Increasing popularity sites & Instagram & Instagram \\
\hline $\begin{array}{l}\text { Frequently type of } \\
\text { participation }\end{array}$ & $\begin{array}{l}\text { surfing universities they considered } \\
\text { attending on any digital media platform }\end{array}$ & $\begin{array}{l}\text { web browsing universities they } \\
\text { considered attending on any digital } \\
\text { media platform }\end{array}$ \\
\hline $\begin{array}{l}\text { Most influential information } \\
\text { during the university search } \\
\text { process through digital } \\
\text { marketing }\end{array}$ & $\begin{array}{l}\text { Study program or course offered and } \\
\text { university entry information }\end{array}$ & $\begin{array}{l}\text { university entry information, subject } \\
\text { information }\end{array}$ \\
\hline Least influential information & University history and events happening & University internal activities \\
\hline $\begin{array}{l}\text { Kind of information or } \\
\text { impressions collected }\end{array}$ & $\begin{array}{l}\text { read the information regarding } \\
\text { university course offered and entry } \\
\text { requirements as the thing that make } \\
\text { them interested }\end{array}$ & $\begin{array}{l}\text { information regarding university entry } \\
\text { requirements and course offered }\end{array}$ \\
\hline $\begin{array}{l}\text { The reason of using digital } \\
\text { marketing before making a } \\
\text { decision to select particular } \\
\text { university }\end{array}$ & $\begin{array}{l}\text { to collect information relate to university } \\
\text { considered joining and to feel the } \\
\text { impression relate to university } \\
\text { considered joining }\end{array}$ & $\begin{array}{l}\text { to find information relate to university } \\
\text { and entry requirements }\end{array}$ \\
\hline $\begin{array}{l}\text { The impact of digital } \\
\text { marketing on university choice } \\
\text { process }\end{array}$ & $\begin{array}{l}\text { to ensure they select the right university } \\
\text { and address all the requirements } \\
\text { required }\end{array}$ & $\begin{array}{l}\text { to find out university information } \\
\text { regarding entry requirements and } \\
\text { university course offered }\end{array}$ \\
\hline
\end{tabular}

On responding question regarding application of digital marketing in HEI's environment participant from university marketing division explain that "So for digital marketing it is promising...I have a view of using the website, continue to use social media, and other electronic media. So in university itself we do not miss the opportunity to use these media as a tool of promotion because it fast and cheap, easy to access and inevitably the university must involve such media as the changing technological advancement. While, for other Higher Education Institutions, they have the same 
opportuny, they also try to compete for students by employing such digital media." Another participant mentioned that "digital marketing means in various forms, there are websites, there are social media, and there are we (Web-Public Relations) as well. Actually very helpful because not everyone access to here directly, so through the media we have, we can provide enough information in the form of data, news, or pictures or photographs, documentation of activities also exist." Based on those explaination, it can be seen that digital marketing in the HEI environment plays as a marketing strategy that utilise websites, social media, and other electronic media since it fast and inexpensive promotional tools, as well as very helpful for helping people to obtain information without having a travel to come directly to the university.

On the other hand, the student explained that University also follow the habit of the millennial generation who want obtain information quickly, accessible, and always up to date. Those information can be achieved through digital platforms which provide information coverage wide spread. On responding this questions, student mention that "In my opinion, the use of digital marketing is very influential and beneficial for all university stakeholders to connects each other globally in the digital world." Another students mentioned that Website is one of the digital marketing channels where there is a collection of pages that display information on text data, still images or motion data, animated data, sound, video and or a combination of all, both static and dynamic and can be accessed using internet networks.

In addition to student comments, university marketers explained that digital marketing in the HEI environment helps stakeholders and shareholders find information and communicate with each other, assist existing problems both administrators and among university faculty and departments. Digital marketing in HEI's environment is a tool to introduce every part of the university, help stakeholder and government to know the extent of university achievement. However, to obtain the maximum benefit of digital media, HEI asked to be aware and have a clear and a comprehensive understanding when employ digital tools as marketing strategies so that its marketing objectives are obvious. This objectives included why they employ digital platforms to marketing their institutions, what are their tactics, what are the key performance indicators, and who are their target market.

Students as university customers have their own digital expectations of university digital marketing. As a generation that is more digitally sophisticated than any previously, students expect to be involved to use this method that suit to their personal preferences. A views from a student regarding the university's digital marketing that "so if I can say that this university is one of the universities with good presence of digital marketing, because even in Instagram, this university has many things to inform, for example about university dormitory, and students information regarding university equipment for orientation program. So, every little things of information is specify in university official social media."

The results of interviews can be understood that the use of digital marketing in the HEI environment receive a good and positive perceptions among students. Those students expected that university should have an awareness how to engage directly with students and what outcomes they could expected as a return for their investment. The return on investment expected by university from students such as students' feedback, usually can be described as student type of response regarding their digital marketing. In addition to the comments, digital media provides opportunities for students to more responsive to obtain the information by giving questions and comments in digital marketing 
channels such as about scholarship, academic calendar, tuition fee, register to prospective student, faculty and all about their major. Digital marketing has several channels or tools, but not all channels have similar potential and suitable for several organizations particularly in the higher education sector. Determining the right platform for HEI can be complicated, but if HEI learns to employ digital marketing properly they will get a return for their investment since all things in the digital world can be tracked and measured. Below the summary of these findings.

Table 2. Summary of the Research Findings regarding the process of students' choice of university based on Students and University Marketing Division

\begin{tabular}{|c|c|c|}
\hline \multirow{2}{*}{$\begin{array}{l}\text { Students' decision } \\
\text { making process }\end{array}$} & \multicolumn{2}{|l|}{ Description } \\
\hline & Students & University Marketing Division \\
\hline Problem recognition & $\begin{array}{l}\text { "Before become a university student I } \\
\text { rarely used the website. However, to } \\
\text { identify the problem or need, I turn to } \\
\text { search for information through internet } \\
\text { about the faculty, tuition fees, and the } \\
\text { registration. Like that. To find the source } \\
\text { of information is actually difficult." }\end{array}$ & $\begin{array}{l}\text { "Since students looking for information via } \\
\text { smartphones and almost all students or } \\
\text { prospective students have this devices, our } \\
\text { strategy is to put all the infrormation about } \\
\text { university through website to easier found } \\
\text { by them." }\end{array}$ \\
\hline Information search & $\begin{array}{l}\text { "For me, accessing digital marketing at the } \\
\text { university assisted us to find information } \\
\text { about the university subject, students } \\
\text { activities, and other related information." }\end{array}$ & $\begin{array}{l}\text { "The information we share through the } \\
\text { website is successful to attract students. It } \\
\text { can be seen from the students enrollment } \\
\text { rate every years." }\end{array}$ \\
\hline Evaluation alternatives & $\begin{array}{l}\text { "Looking at social media for other people } \\
\text { comments not only stimulated me to select } \\
\text { this university, but to make sure this } \\
\text { information, I do explored the official } \\
\text { website of the university before making a } \\
\text { choice" }\end{array}$ & $\begin{array}{l}\text { "The students who visit the website, find all } \\
\text { the information needed and one of the } \\
\text { information could be relevant for them, so } \\
\text { they may not look at other sources." }\end{array}$ \\
\hline Purchase decision & $\begin{array}{l}\text { "I did not only rely on the social media } \\
\text { which sometimes its helpful, however, I } \\
\text { still utilise other sources of information } \\
\text { such as university website and my parents', } \\
\text { families, and teachers in high school's } \\
\text { viewpoints as a consideration." }\end{array}$ & $\begin{array}{l}\text { "Students decide to choose this university, } \\
\text { mostly they looking at our website first to } \\
\text { find the right information for them. I think } \\
\text { students choose the university are not only } \\
\text { look for the favorite subjects, but also to } \\
\text { find information regarding the strategy how } \\
\text { to successfully enroll into public } \\
\text { universities." }\end{array}$ \\
\hline Post-purchase decision & $\begin{array}{l}\text { "I feel more confidence by using } \\
\text { comprehensive sources regarding } \\
\text { university choice." }\end{array}$ & $\begin{array}{l}\text { "They would follow the social media and of } \\
\text { course they will not miss out any } \\
\text { information, especially if they are already } \\
\text { being a student, the information they need } \\
\text { could be about scholarship. We always } \\
\text { share it in our social media." }\end{array}$ \\
\hline
\end{tabular}

Digital marketing on student decision making processes is something that should change the purpose of digital marketing in educational institutions which previously only made it as trend to provide information either to stakeholders or shareholders of a process that does not become just to know, especially students. Directing students to have a knowledge, making decisions (new thoughts or views) and solving problems in HEI as a success of the use of HEI's digital marketing, it is building a deeper relationship between HEIs and students because both of them understand needs each other's such as the term 'mutualism symbiosis'. 
Noel (2009) states that marketing is a "satisfying consumers' needs profitably 'if marketers understand their consumers' needs and satisfy these needs. This is evidenced by the results of interviews obtained from the public university showing that the marketing team from the university still did not fully understand the needs of prospective students or scholars, they only followed the development of technology without seeing the real strategies and tactics so that the outcomes obtained were not satisfactory. The result of interview from students also explains that their university do not completely understand the real needs of students who always wanted to get satisfactory service both from the point of view of web design, the information conveyed and other digital marketing, there are even some misconceptions by students about who manages digital platforms in their university. On the other hand, students also do not deny that digital marketing helps them in making decisions, they emphasize that the information they get through digital marketing is only as support in the decision making process.

In this case, researcher also needs to obtain data regarding student decision making process in Higher Education Institutions (HEI). According to Kotler and Armstrong (2014), consumers passed through all five stages with every purchase but in more routine purchases, consumers often skip or reverse some of these stages. This theory supports and match the conditions faced by students in HEI.

All participants explain that digital marketing does trigger a need for the student. Identifying an education need is the first and important step in the student decision making process, as student must have a need for education which can bring out better future to career path and prestige itself to get extensive knowledge through a degree. Digital marketing plays and important role in influencing students in identifying a need for education and through the digital space Universities can align their marketing strategies to target students.

The next step illustration digital marketing's engagement impact on student choice, which consists of information search and evaluation of alternatives in the student decision making process. According to Kotler and Armstrong (2014), an interested consumer may or may not search for more information. If the consumer's drive is strong and a satisfying product is near at hand, he or she is likely to buy it then. If not, the consumer may store the need in memory or undertake an information search related to the need.

The student processes information to arrive at the true education choices. Unfortunately, students do not use a simple and single evaluation process in all choice situations. How students go about evaluating choice alternatives depends on the individual and the specific choice situation, instead they choice on impulse and rely on intuition, sometimes because family's choice. On fifth stage, can explained more as the student retention to university or a compulsory conditions to students get update information from their university.

Explanation above to be better understood in the meaning of engagement of digital marketing, researcher add theory of engagement so easier to understanding. Jarmon et al. (2009) in Samuelson (2011) mentioned that there are three key elements of engagement namely interactivity, connectivity, and access. This opinion supports the results of interviews conducted to college students where the digital era is currently making prospective students look for information needed about the universities they will choose through the internet. Digital marketing carried out by universities through various digital media owned by universities that are connected to each other helps them in getting the 
information they need such as accreditation, tuition fees, and electives. In addition, for students, they feel that they need to look for the information through the campus digital media to find out information about activities organized by the campus such as program of student creativity and scholarship. This easy access makes students look for information about the campus through the campus website.

\section{Conclusions}

This study deals with the topic of applying digital marketing in university choice process. In order to create a complete picture of the research scope, the interrelation of digital marketing and student's decision-making behaviour was described in general terms. The research indicated that the internet is the most frequently medium used among student population for both general information about university, and for information about student general activities. When analysing the results of the research related to the student information about the university, it can be concluded that students are prefer familiar source of information fitted to their activities and mobility. Research has shown that students were more rely on internet and they were search and browse university before either through the official media such as Facebook, Twitter, Instagram or university website. Information about student activities was gathered from other students, whereas equally popular was sharing the information via Facebook. A very small number of students are informed through other websites and offline media such as newspapers, radio or television. Therefore, university should invest more with great emphasis on digital medial especially social networks and the usage of mobile phones to access the internet. To summarize, it was determined that, in its current form, UB digital marketing was attracting predominately for young students. Most respondents indicated that information supplied on social media was influencing them to choose the university. In UB case, results suggested that students value the digital media choose the university not due to its success in branding but rather in its convenience compared to other media. Furthermore, applicants became aware of UB mostly through referrals or by searching the university's website. UB's digital marketing should switch to a having a more proactive role in communicating personalized and relevant promotional material to prospective students; while addressing these individuals concerns for recognition and reputation.

\section{References}

Beatty, S. E., \& Smith, S. M. (1987). External search effort: An investigation across several product categories. Journal of Consumer Research, 14(1), 83-95.

Bonnema, J., \& Van der Waldt, D. L. R. (2008). Information and source preferences of a student market in higher education. International Journal of Education Management, 22(4), 314-327.

Braun, V., \& Clarke, V. (2006). Using thematic analysis in psychology. Qualitative Research in Psychology, 3(2), 77-101. doi:10.1191/1478088706qp063oa

Buetow, S. (2010). Thematic analysis and its reconceptualization as 'saliency analysis.' Journal of Health Services Research and Policy, 15(2), 123-125. doi:10.1191/1478088706qp063oa

Chapman, D. W. (1981). A Model of Student College Choice. The Journal of Higher Education, 52(5), 490-505.

Choi, J., \& Lee, K. H. (2003). Risk perception and e-shopping: A cross-cultural study. Journal of Fashion Marketing and Management 7(1), 49-64.

Constantinides, E., \& Fountain, S. J. (2008). Web 2.0: Conceptual foundations and marketing issues. Journal of Direct, Data and Digital Marketing Practice, 9(3), 231-244. 
Curran, Kevin, Sarah Graham, and Christopher Temple. 2011. "Advertising on Facebook." International Journal of E-Business Development 1: 26-33.

Engel, J. F., Blackwell, R. D., \& Miniard, P. W. (1995). Consumer Behavior (8th edn ed.). Fort Worth: Dryden Press.

Ernst \& Young. (2012). University of the Future: A thousand year old industry on the cusp of profound change. Retrieved from http://www.ey.com/Publication/vwLUAssets/University_of_the_future/\$FILE/University_of_the_futu re_2012.pdf

GetCraft.com. 2017. "White Paper Final: Indonesia's Digital and Content Marketing Reports in 2017”. GetCraft.com. Retrieved from https://www.slideshare.net/digitalinasia/indonesia-digital.

Hanson, K., \& Litten, L. (1982). Mapping the Road to Academia: A Review of Research on Women, Men, and the College Selection Process. . In P. Perun (Ed.), The Undegraduate Woman: Issues in Education. Lexington, MA: Lexington.

Hartmen, K. E. (1998). The Internet \& college admissions: implications and opportunities. Change, 30(2), 54-55.

Hossler, D., \& Gallagher, K. (1987). Studying student college choice: a three-phase model and the implications for the policymakers. College and University, 2 Spring(3), 207-221.

Jackson, G. A. (1982). Public efficiency and private choice in higher education. Educational Evaluation and Policy Analysis, 4(2), 237-247.

Kreutzer, R. T., \& Hinz, J. (2010). Möglichkeiten und Grenzen von Social Media Marketing. Berlin School of Economics and Law (HWR Berlin): IMB Institute of Management Berlin.

Kotler, P. \& Armstrong, G. 2014. Principles of Marketing Global Edition (15 th Ed). Harlow: Pearson Education.

Kotler, P., \& Fox, K. F. A. (1995). Strategic Marketing for Educational Institutions (2nd edn ed.). Englewood Cliffs, New Jersey: Prentice-Hall.

Kotler, P., \& Keller, K. L. (2009). Marketing Management (13th edn ed.). Upper Saddle River, New Jersey: Pearson Prentice Hall.

Kusumawati, A. 2013. Students' Perception of Choice Criteria in the Selection of an Indonesian Public University. University of Wollongong Thesis Collection. Retrieved from http://ro.uow.edu.au/theses/3933/

Mangold, W. G., \& Faulds, D. J. (2009). Social media: The new hybrid element of the promotion mix. Business horizons, 52(4), 357-365.

Martin, C. M. 2015. Social Media Engagement and Collegiate Recruitment: An Examination of the Use of Social Networks in the College Recruitment and Student Choice Processes. Dissertations. Paper 93. Retrieved from http://digitalcommons.wku.edu/diss/93

Mateos, M. B., Mera, A. C., González, F. J. M., \& López, Ó. R. G. (2001). A new Web assessment index: Spanish universities analysis. Internet Research: Electronic Networking Applications and Policy, 11(3), 226-234.

McColl-Kennedy, J. R., \& Fetter Jr, R. E. (1999). Dimensions of consumer search behavior in services. Journal of Services Marketing 13(3), 242-265.

Murray, K. B. (1991). A test of services marketing theory: Consumer information acquisition activities. Journal of Marketing, 55 (1 (January), 10-25.

Nuffic. 2015. "Indonesian Education System". Netherlands: Nuffic. Retrieved from https://www.nuffic.nl/en/publications/find-a-publication/education-system-indonesia.pdf

Perreault, W. D., \& McCarthy, E. J. (2005). Basic Marketing: A Global-Managerial Approach (15th edn ed.). Boston, London: McGraw-Hill. 
Patrutiu Baltes, L. (2015). Content marketing - the fundamental tool of digital marketing. Bulletin of the Transilvania University of Brasov. Series V: Economic Sciences , 8 (2), 111-118.

Pimpa, N., \& Suwannapirom, S. (2008). Thai students' choices of vocational education: marketing factors and reference groups. Educational Research for Policy and Practice, 7(2), 99-107.

PwC. 2015. "The 2018 digital university: Staying relevant in the digital age", accessed on February $5^{\text {th }} 2018$ from https://www.pwc.co.uk/assets/pdf/the-2018-digital-university-staying-relevant-in-thedigital-age.pdf

Reddy, G. 2016. Digital Marketing Impact on the Consumer Decision Makin Process in Nike's Customer Retail Operations in South Africa. Gordon Institute of Business Science. Retrieved from https://repository.up.ac.za/handle/2263/59756

Schiffman, L. G., \& Kanuk, L. L. (2007). Consumer Behavior (9th edn ed.). New Jersey: Prentice Hall.

Shankar,Venkatesh, Jeffery Inman, Murali Mantrala, Eileen Kelley, and Ross Rizley. 2011. "Innovations in Shopper Marketing: Current Insights and Future Research Issues." Journal of Retailing 1:s29-s42, doi:10.1016/j.jretai.2011.04.007.

Sherman, R. 2014. "Proving the Value of Digital Marketing in Higher Education". OHO Interactive. Retrieved from https://www.oho.com/blog/proving-value-digital-marketing-best-practices-guide-nowavailable

Stokes, R. 2011. E-Marketing: The Essential Guide to Online Marketing (4 ${ }^{\text {th }}$ Ed). South Africa: Quirk eMarketing (Pty) Ltd. ISBN: 978-0-620-41135-6. Retrieved from www.creativecommons.org.

Syahid, A. \& Tulung, J. M. 2016. Quality Assurance and Accreditation in Religious Higher Education: Indonesian Cases. International Journal of Humanities and Social Science Invention, Volume 5 Issue 10, PP.52-67. Retrieved from www.ijhssi.org

Wagner, K., \& Fard, P. Y. (2009). Factors Influencing Malaysian Students' Intention to Study at a Higher Educational Institution. Chinese American Scholars Association, New York, New York, USA Retrieved 11 July, 2009, from http://www.g-casa.com/PDF/malaysia/Wagner-Fard.pdf 